\title{
Complete sequence and comparative analysis of the chloroplast genome of Plinia trunciflora
}

\author{
Maria Eguiluz ${ }^{1}$, Priscila Mary Yuyama ${ }^{2}$, Frank Guzman ${ }^{2}$, Nureyev Ferreira Rodrigues ${ }^{1}$ and Rogerio \\ Margis ${ }^{1,2}$ \\ ${ }^{1}$ Programa de Pós-Graduação em Genética e Biologia Molecular, Universidade Federal do Rio Grande do \\ Sul (UFRGS), Porto Alegre, RS, Brazil. \\ ${ }^{2}$ Departamento de Biofísica, Centro de Biotecnologia, Laboratório de Genomas e Populações de Plantas, \\ Universidade Federal do Rio Grande do Sul (UFRGS), Porto Alegre, RS, Brazil.
}

\begin{abstract}
Plinia trunciflora is a Brazilian native fruit tree from the Myrtaceae family, also known as jaboticaba. This species has great potential by its fruit production. Due to the high content of essential oils in their leaves and of anthocyanins in the fruits, there is also an increasing interest by the pharmaceutical industry. Nevertheless, there are few studies focusing on its molecular biology and genetic characterization. We herein report the complete chloroplast (cp) genome of $P$. trunciflora using high-throughput sequencing and compare it to other previously sequenced Myrtaceae genomes. The cp genome of $P$. trunciflora is 159,512 bp in size, comprising inverted repeats of 26,414 bp and single-copy regions of 88,097 bp (LSC) and 18,587 bp (SSC). The genome contains 111 single-copy genes (77 protein-coding, 30 tRNA and four rRNA genes). Phylogenetic analysis using $57 \mathrm{cp}$ protein-coding genes demonstrated that $P$. trunciflora, Eugenia uniflora and Acca sellowiana form a cluster with closer relationship to Syzygium cumini than with Eucalyptus. The complete $\mathrm{cp}$ sequence reported here can be used in evolutionary and population genetics studies, contributing to resolve the complex taxonomy of this species and fill the gap in genetic characterization.
\end{abstract}

Keywords: Jaboticaba, Myrtaceae, chloroplast genome, next-generation sequencing.

Received: April 18, 2017; Accepted: July 13, 2017.

Plinia trunciflora (O.Berg) Kausel, synonym Myrciaria trunciflora O.Berg, is a native Brazilian tree that belongs to the Myrtaceae family and is widely distributed in the southern and southeastern areas of Brazil (Sobral et al., 2012). Among all identified Plinia sp. species, $P$. cauliflora (DC.) Berg (synonym M. cauliflora (Mart.) O.Berg), P. jaboticaba (Vell.) Berg (synonym M. jaboticaba O.Berg) and P. trunciflora are endemic to Brazil. All of these species produce a similar grape-like edible fruit, known as jaboticaba, which presents a sweet jelly-like white pulp covered by a purple peel. Jaboticaba $(P$. trunciflora) has attracted attention because of its significant levels of phenolic compounds associated with health benefits, such as antidepressant and antioxidant effects and the prevention of neurodegenerative diseases and diabetes (Stasi and Hiruma-Lima, 2002; Sacchet et al., 2015). These benefits have largely been attributed to the capacity of these compounds to prevent or reduce oxidative stress. Addi-

Send correspondence to Rogerio Margis. Departamento de Biofísica, Centro de Biotecnologia, Laboratório de Genomas e Populações de Plantas, Universidade Federal do Rio Grande do Sul (UFRGS), Avenida Bento Gonçalves 9500, Prédio 43432, Sala 206, Porto Alegre, RS, CEP 91501-970 Brazil. E-mail: rogerio.margis@ufrgs.br. tionally, jaboticaba ( $P$. trunciflora) is largely consumed fresh or used to make jellies, juices, wines, spirits and vinegar (Balerdi et al., 2006).

Despite the nutritional and productive recognized importance of this species, the taxonomic classification is still controversial. This is mostly so because it is based on morphological evaluation of the trees, fruits and seeds, regarding physical, chemical, physicochemical, and germinal characters that have shown the existence of variability (Guedes et al., 2014). Therefore, molecular studies are needed to better clarify the phylogenetic relationships among the species from this genus.

The chloroplast (cp) genome is a circular molecule of double-stranded DNA that consists of four distinct regions, a large and a small single copy region (LSC and SSC, respectively) separated by two inverted repeat regions (IRa and $\mathrm{IRb}$ ). Despite the high degree of conservation in its structure, gene content and organization, the presence of mutations, duplications and rearrangements of genes make it an attractive option for phylogenetic studies (Costa et al., 2016). In the case of Myrtaceae, there are only few phylogenetic and evolutionary studies based on cp genes (Craven and Biffin 2005; Payn et al., 2007; Biffin et al., 2010; Bayly 
et al., 2013; Eguiluz et al., 2017; Machado et al., 2017), and there are even less that include the Plinia genus (Vasconcelos et al., 2017).

In this study, young leaves from a Plinia trunciflora tree harvested in Gravataí, RS, Brazil (latitude (S): 29 51'52"; longitude (W): 50 $\left.53^{\prime} 53^{\prime \prime}\right)$ were used to extract total DNA by the CTAB method (Doyle and Doyle, 1990). DNA quality was evaluated by electrophoresis in a $1 \%$ agarose gel, and DNA quantity was determined using a NanoDrop spectrophotometer (NanoDrop Technologies, Wilmington, DE, USA). One genomic paired-end library of 100 nt length was generated by Fasteris SA (Plan-lesOuates, Switzerland) using an Illumina HiSeq2000 platform (Illumina Inc., San Diego, CA, USA). The paired-end sequence reads were filtered against 42 Myrtaceae cp genomes (Table S1) using BWA software with two mismatches allowed (Li and Durbin, 2009). The obtained reads were assembled de novo with ABySS software (Simpson et al., 2009). The cp genome scaffolds were orientated using cp genome sequences of Eucalyptus globulus, Eucalyptus grandis and Eugenia uniflora L. using BLASTN (Camacho et al., 2009). A gap region was filled in by Sanger sequencing using primers F: 5' GGGTTATCCTGCACTTGGAA and R: 3' TGCTGTCGAAGCTCCATCTA. Genes were annotated using DOGMA (Wyman et al., 2004) and BLAST homology searches. tRNAs (transfer RNA) were predicted using tRNAscan-SE program (Schattner et al., 2005 ) and confirmed by comparison with the appropriate homologs in E. globulus. The circular cp genome map was drawn using OGDRAW online program (Lohse et al., 2007). For the phylogenetic analysis, a set of $57 \mathrm{cp}$ protein-coding sequences (Table S2) from 56 species belonging to Malvids (Eurosids II) (Table S3) were used with Vitis vinifera serving as outgroup. Nucleotide sequences were aligned using MUSCLE available in MEGA version 6.0 (Tamura et al., 2013), and a Bayesian tree was generated using MrBayes version 3.1.2 (Ronquist and Huelsenbeck, 2003 ) with $5,000,000$ generations sampled every 100 generations and discarding the first $25 \%$ of trees as burn-in, with posterior probability (PP) values for each node. The GTR $+\mathrm{I}+\mathrm{G}$ nucleotide substitution model determined by
MODELTEST version 3.7 (Posada and Crandall, 1998) was used. The phylogenetic tree was rooted and visualized using FigTree software (http://tree.bio.ed.ac.uk/software/figtree/).

A total of $148,824,244$ raw Illumina paired-end reads from the $P$. truncliflora nuclear genome were filtered against 42 Myrtaceae cp genomes. The 8,912,157 obtained reads were de novo assembled into non-redundant contigs and singletons covering about $99 \%$ of the genome (minimum coverage $=144$ reads, maximum coverage $=18,789$ reads). Two final large scaffolds were obtained and joined into a cp circular genome using Sanger sequencing. The complete cp genome of $P$. trunciflora is $159,512 \mathrm{bp}$ in size and was submitted to GenBank (accession number: KU318111). The size is similar to that of other Myrtaceae species (Eguiluz et al., 2017; Machado et al., 2017). The cp genome included an LSC region of 88,097 bp, an SSC region of 18,587 bp and a pair of inverted repeats (IRa and $\mathrm{IRb}$ ) of 26,414 bp each (Figure 1). Coding regions comprise $47.2 \%, 13.3 \%$ correspond to rRNAs and tRNAs, and $39.5 \%$ of the genome comprises non-coding regions, including introns, pseudogenes and intergenic spacers (Table 1). In general, all genomic features showed similarity in structure and gene abundance with other Myrtaceae species (Bayly et al., 2013; Eguiluz et al., 2017; Machado et al., 2017). The genome contained 131 genes in total, which includes 111 single-copy genes corresponding to 77 protein-coding genes, 30 transfer RNA (tRNA) genes and four ribosomal genes (rRNA) (Figure 1, Table 1). The $y c f 1, y c f 2$ and $y c f 15$ sequences were annotated as pseudogenes based on the presence of many stop codons in their coding sequences and by comparison with sequences of E. globulus and S. cumini. Of the 131 genes in P. trunciflora, seven of the tRNAs genes and all four rRNA genes occurred within the IR regions and consequently were duplicated (Table 1). The cp genome has 20 intron-containing genes: 12 protein coding genes and six tRNA genes which contain one intron, and the $c l p P$ and $y c f 3$ genes that contain two introns each. The rps 12 gene is a trans-spliced gene with the 5'end located in the LSC region and the duplicated 3'end in the IR

Table 1 - Summary of the Plinia trunciflora chloroplast genome characteristics.

\begin{tabular}{lc}
\hline Feature & Plinia trunciflora \\
\hline Total cpDNA size & $159,512 \mathrm{bp}$ \\
LSC size (bp) & $88,097 \mathrm{bp}$ \\
SSC size (bp) & $18,586 \mathrm{bp}$ \\
IR size (bp) & $26,414 \mathrm{bp}$ \\
Protein coding regions (\%) & $60.48 \%$ \\
rRNA and tRNA (\%) & $13.3 \%$ \\
Introns size (\% total) & $10.65 \%$ \\
Intergenic sequences and pseudogenes size (\%) & $28.9 \%$ \\
\hline
\end{tabular}

\begin{tabular}{lc}
\hline Feature & Plinia trunciflora \\
\hline Number of genes & 131 genes \\
Number of different protein coding genes & 77 \\
Number of different tRNA genes & 30 \\
Number of different rRNA genes & 4 \\
Number of different duplicated genes & 16 \\
Pseudogenes & 3 \\
GC content (\%) & $37 \%$ \\
\hline
\end{tabular}

rergenic sequences and pseudogenes size (\%) $28.9 \%$ 


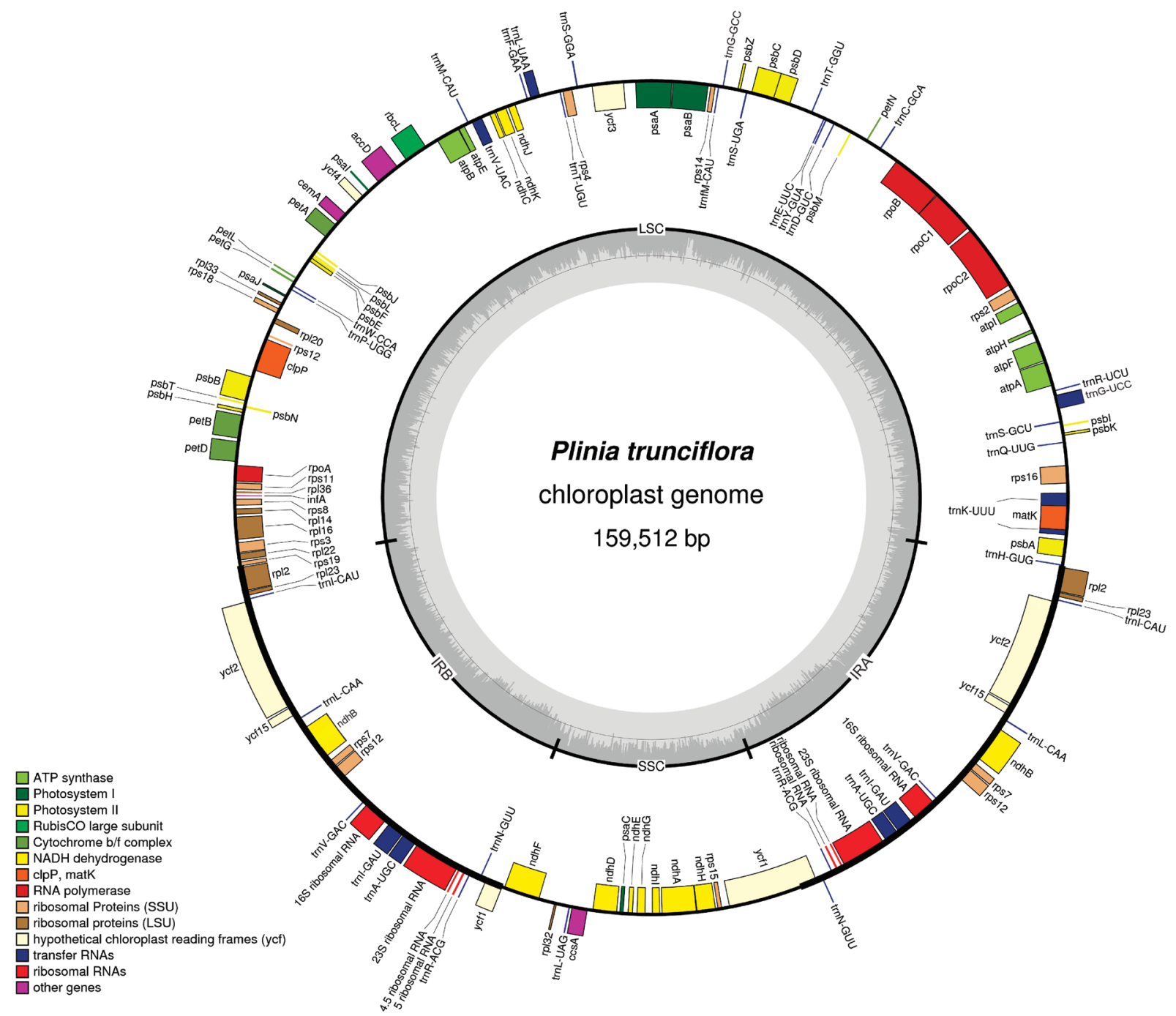

Figure 1 - Gene map of the Plinia trunciflora chloroplast genome. The structure of the cp genome consists of one large and small single copy (LSC and SSC, respectively) and a pair of inverted repeats (IRa and IRb). Genes drawn inside the circle are transcribed counterclockwise and those outsides are clockwise. Genes belonging to different functional groups are indicated by different tonalities. The darker gray in the inner circle corresponds to GC content, while the lighter gray corresponds to AT content.

regions. The trnK-UUU has $2,529 \mathrm{bp}$, with the largest intron encompassing also the matK gene.

The whole cp genome analysis revealed that the $\mathrm{cp}$ genomes of P. trunciflora and E. uniflora are shorter in comparison to other Myrtaceae, such as E. globulus, E. grandis, E. uniflora and S. cumini, (Figure 2). Despite its size, the total length of introns in P. trunciflora $(16,972 \mathrm{pb})$ is the largest in Myrtaceae, e.g. S. cumini presents 14,469 bp and the same is observed in E. globulus and E. grandis. The size of the intergenic spacer located between the IRa/LSC border and the first gene of LSC in P. trunciflora is more similar to Eucalyptus species than its closer species E. uniflora (Figure 2). The comparison of the $n d h K$ gene of $P$. trunciflora, with $678 \mathrm{bp}$, indicated a smaller gene size than that in other plants, such as E. uniflora (858 pb), $S$. cumini ( $855 \mathrm{bp})$, E. globulus ( $855 \mathrm{bp}$ ) and E. grandis ( 853 bp). The same size (678 bp) for this gene is found in
Arabidopsis thaliana. The effective size of the coding sequence is confirmed by the presence of a thymine in position 53,811 bp in the cp genome from P. trunciflora that creates a stop codon and makes this gene shorter than in other Myrtaceae.

Our phylogeny includes the sister relationship of the orders Brassicales, Malvales and Sapindales and the orders Geraniales and Myrtales. All these results agree with previous studies based on multiple genes or complete cp genomes (Ruhfel et al., 2014). By analyzing the Myrtaceae family clade we showed that $P$. trunciflora, E. uniflora and Acca sellowiana form a single cluster of Neotropical Myrtaceae, and that this clade has a shorter genetic distance with $S$. cumini than to the Australian Myrtaceae clade (Figure 3). Additionally, our analysis corroborates that Corymbia gummifera is paraphyletic in respect to Angophora. A previous phylogenetic analysis using certain $\mathrm{cp}$ 

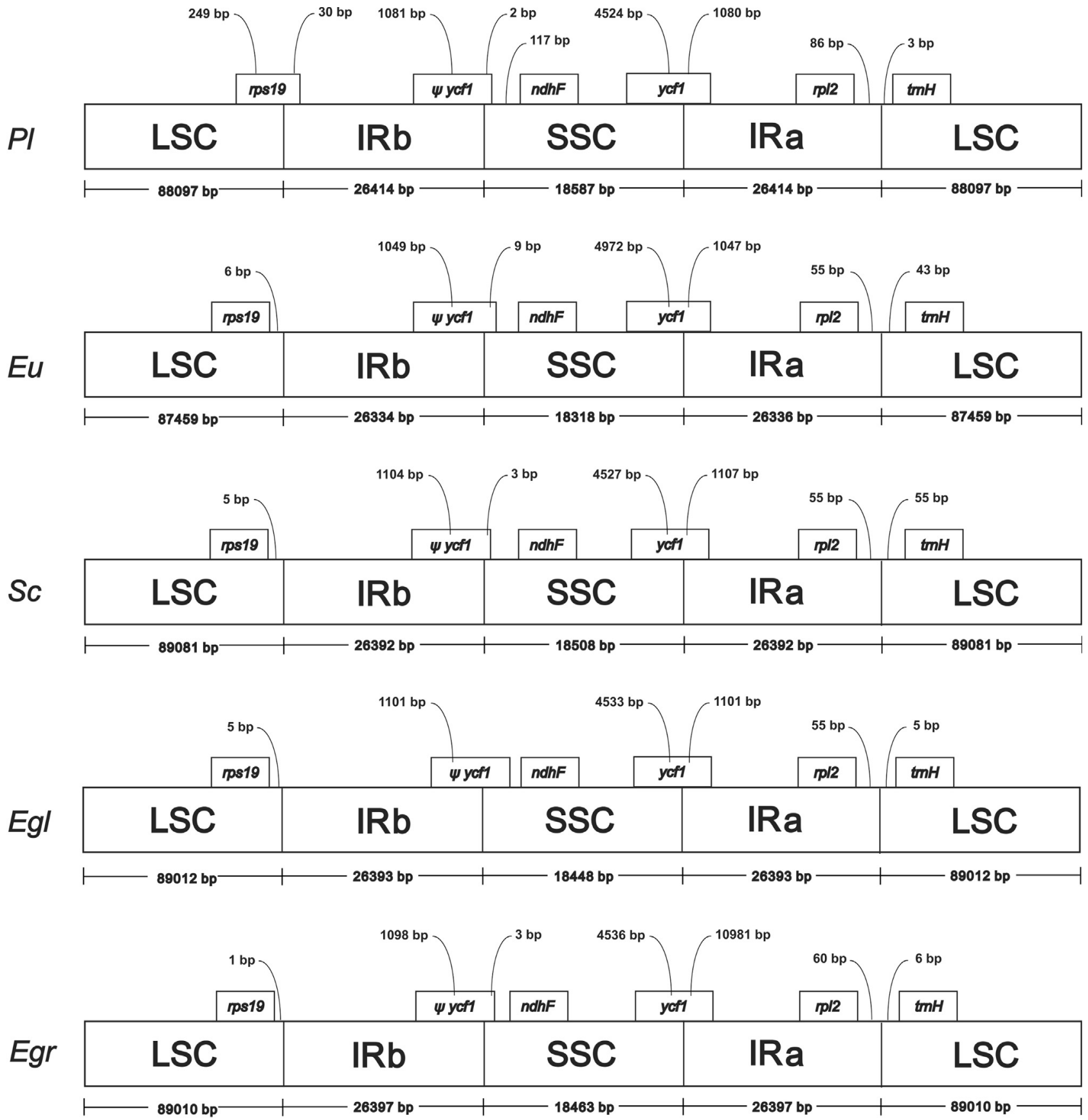

Figure 2 - Comparison of the borders of LSC, SSC and IR regions among five chloroplast genomes. Boxes above the main line indicate the predicted genes, while pseudogenes at the borders are shown by $\Psi$. Variation in rps 19 gene length is displayed at the IRb/LSC borders of Plinia trunciflora, Eugenia uniflora, Syzygium cumini, Eucalyptus globulus and Eucalyptus grandis, but only in P. trunciflora, this gene is located at IRb and LSC regions. This figure is not drawn to scale.

genes (ITS, matK and $n d h F$ ) of Myrtaceae species showed that Eucalyptus, Syzygium, Eugenia and Myrciaria (synonym of Plinia) form a distinct clade that is consistent with characteristics of the pollen (Thornhill et al., 2012). As can be observed in the Bayesian tree (Figure 3), Plinia could be paraphyletic in relation to Eugenia and Acca, in agreement with the embryo morphology and studies using cp regions that placed Plinia, Myrciaria and Siphoneugena as the emerging "Plinia group" (Lucas et al., 2007). Taxon sampling and phylogenetic methodology could affect the different results. Therefore, additional complete cp genome sequences will help in the comprehension of the relationship among Myrtaceae species.

The Plinia trunciflora genome represents the first complete cp genome sequence for the genus Plinia and shows a set of features that could be further explored for 


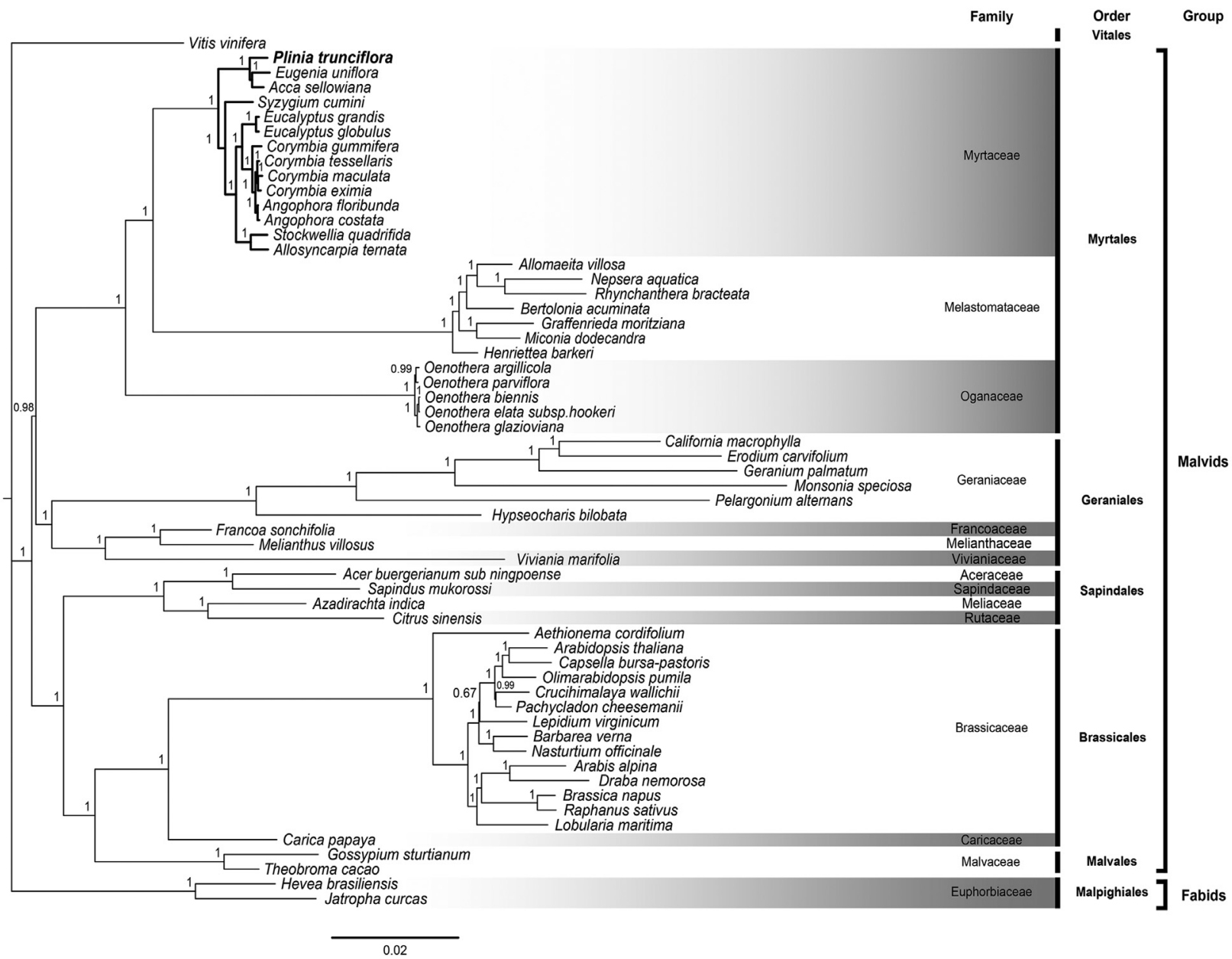

Figure 3 - Phylogenetic tree of Eurosids II based on $57 \mathrm{cp}$ protein-coding genes generated by Bayesian method from 56 species. Bold branches indicate the Myrtaceae species. Numbers above each node are posterior probability values. Family, order and clade are also indicated. Vitis vinifera was considered as outgroup.

population and phylogenetic studies within this group. Moreover, these data increase the genetic and genomic resources available in Myrtaceae by adding a new strategy of organelle genome assembly.

\section{Acknowledgments}

This study was carried out with financial support from the Conselho Nacional de Desenvolvimento Científico e Tecnológico (CNPq), Coordenação de Aperfeiçoamento de Pessoal de Nível Superior (CAPES) and Fundação de Amparo à Pesquisa do Rio Grande do Sul (FAPERGS).

\section{References}

Bayly MJ, Rigault P, Spokevicius A, Ladiges PY, Ades PK, Anderson C, Bossinger G, Merchant A, Udovicic F, Woodrow IE, et al. (2013) Chloroplast genome analysis of Australian eucalypts - Eucalyptus, Corymbia, Angophora, Allosyn- carpia and Stockwellia (Myrtaceae). Mol Phylogenet Evol 69:704-716.

Balerdi CF, Rafie R and Crane J (2006) Jaboticaba (Myrciaria cauliflora, Berg.) a delicious fruit with an excellent market potential. Proc Florida State Hortic Soc 119:66-68.

Biffin E, Lucas EJ, Craven L, Da Costa IR, Harrington MG and Crisp MD (2010) Evolution of exceptional species richness among lineages of fleshy-fruited Myrtaceae. Ann Bot 106:79-93.

Camacho C, Coulouris G, Avagyan V, Ma N, Papadopoulos J, Bealer K and Madden TL (2009) BLAST+: Architecture and applications. BMC Bioinformatics 10:421.

Costa JF, Lin SM, Macaya EC, Fernández-García C and Verbruggenet $\mathrm{H}$ (2016) Chloroplast genomes as a tool to resolve red algal phylogenies: A case study in the Nemaliales. BMC Evol Biol 16:205.

Craven LA and Biffin E (2005) Anetholea anisata transferred to, and two new Australian taxa of Syzygium (Myrtaceae). Blumea 50:157-162.

Doyle JJ and Doyle JL (1990) Isolation of plant DNA from fresh tissue. Focus 12:13-15. 
Eguiluz M, Rodrigues FN, Guzman F, Yuyama P and Margis R (2017) The chloroplast genome sequence from Eugenia uniflora, a Myrtaceae from Neotropics. Plant Syst Evol doi: 10.1007/s00606-017-1431-x.

Guedes MNS, Rufini JCM, Azevedo AM and Pinto NAVD (2014) Fruit quality of jabuticaba progenies cultivated in a tropical climate of altitude. Fruits 69:449-458.

Li H and Durbin R (2009) Fast and accurate short read alignment with Burrows-Wheeler transform. Bioinformatics 25:17541760.

Lohse M, Drechsel O and Bock R (2007) Organellar Genome DRAW (OGDRAW): A tool for the easy generation of high-quality custom graphical maps of plastid and mitochondrial genomes. Curr Genet 52:267-274.

Lucas EJ, Harris SA, Mazine FF, Belsham SR, Lughadha EMN, Telford A, Gasson PE and Chase MW (2007) Suprageneric phylogenetics of Myrteae, the generically richest tribe in Myrtaceae (Myrtales). Taxon 56:1105-1128.

Machado LO, Vieira LD, Stefenon VM, Pedrosa OF, De Souza EM, Guerra MP and Nodari RO (2017) Phylogenomic relationship of feijoa (Acca sellowiana (O.Berg) Burret) with other Myrtaceae based on complete chloroplast genome sequences. Genetica 145:1-12.

Payn KG, Dvorak WS and Myburg AA (2007) Chloroplast DNA phylogeography reveals the island colonisation route of $E u$ calyptus urophylla (Myrtaceae). Aust J Bot 55:673-683.

Posada D and Crandall KA (1998) MODELTEST: Testing the model of DNA substitution. Bioinformatics 14:817-818.

Ronquist F and Huelsenbeck JP (2003) MRBAYES 3: Bayesian phylogenetic inference under mixed models. Bioinformatics 19:1572-1574.

Ruhfel BR, Gitzendanner MA, Soltis PS, Soltis DE and Burleigh JG (2014) From algae to angiosperms-inferring the phylogeny of green plants (Viridiplantae) from 360 plastid genomes. BMC Evol Biol 14:23.

Sacchet C, Mocelin R, Sachett A, Bevilaqua F, Chitolina R, Kuhn F, Boligon AA, Athayde ML, Roman Junior WA, Rosemberg DB, et al. (2015) Antidepressant-like and antioxidant effects of Plinia trunciflora in mice. Evid Based Complement Alternat Med 2015:601503.

Stasi LC and Hiruma-Lima CA (2002) Myrtales medicinais. In: Stasi LC and Hiruma-Lima CA (eds) Plantas Medicinais na Amazônia e na Mata Atlântica. 2nd edition. Editora UNESP, São Paulo, pp 321-330.
Schattner P, Brooks AN and Lowe TM (2005) The tRNAscan-SE, snoscan and snoGPS web servers for the detection of tRNAs and snoRNAs. Nucleic Acids Res 33:W686-W689.

Simpson JT, Wong K, Jackman SD, Schein JE, Jones SJM and Birol I (2009) ABySS: A parallel assembler for short read sequence data. Genome Res 19:1117-1123.

Tamura K, Stecher G, Peterson D, Filipski A and Kumar S (2013) MEGA6: Molecular Evolutionary Genetics Analysis version 6.0. Mol Biol Evol 30:2725-2729.

Thornhill AH, Hope GS, Craven LA and Crisp MD (2012) Pollen morphology of the Myrtaceae. Part 4: Tribes Kanieae, Myrteae and Tristanieae. Aust J Bot 60:260-289.

Wyman SK, Jansen RK and Boore JL (2004) Automatic annotation of organellar genomes with DOGMA. Bioinformatics 20:3252-3255.

Vasconcelos NCT, Proença EBC, Ahmad B, Aguilar SD, Aguilar R, Amorim SB, Campbell K, Costa RI, De-Carvalho SP, Faria EQJ, et al. (2017) Myrteae phylogeny, calibration, biogeography and diversification patterns: Increased understanding in the most species rich tribe of Myrtaceae. Mol Phylogenet Evol 109:113-137.

\section{Internet Resources}

Sobral M, Proença C, Souza M, Mazine F and Lucas E (2012) Myrtaceae in lista de espécies da flora do Brasil. Jardim Botânico do Rio de Janeiro [online], http://floradobrasil.jbrj.gov.br (accessed 16 September 2015).

\section{Supplementary material}

The following online material is available for this article:

Table S1 - List of 42 Myrtaceae chloroplast genomes used in chloroplast genome assembling of Plinia trunciflora.

Table S2 - List of 57 chloroplast protein coding genes used in the phylogenetic analysis.

Table S3 - List of 56 plastome sequences of Rosids included in the Bayesian phylogenetic analysis.

\section{Associate Editor: Guilherme Corrêa de Oliveira}

License information: This is an open-access article distributed under the terms of the Creative Commons Attribution License (type CC-BY), which permits unrestricted use, distribution and reproduction in any medium, provided the original article is properly cited. 